\title{
Technology-based College English Learning, Teaching and Acquisition in Inner Mongolia, China
}

\author{
Hongling Bao \\ Chifeng University, Yingbin Road No.1, Hongshan District, Chifeng, Inner Mongolia
}

Keywords: Technology; College English; Inner Mongolia

\begin{abstract}
Language development could be influenced by many factors and one of them, especially in today's super scientific era, would be technology. This paper shows the easy, enjoyable and effective impact of technology on English as a third language in Inner Mongolia, China around in the first decade of $21^{\text {st }}$ century by analyzing the technology-based college English learning, teaching and acquisition in some major higher education institutes based on the author's individual experience. Illustrating some relation between English and technology, this paper advocates a broader application of technology in second language related study, work and researches.
\end{abstract}

\section{Introduction}

Inner Mongolia is one of the autonomous regions in China with Mongolian and Chinese both as the official languages. Mongolian is the largest ethnic group in this region. For Mongolians like me, Mongolian is our mother language, Chinese is the second language. Besides these two languages, there is also one more language we have to mention which may not be used widely in daily life or official field. That is English. Then when is it used and who will be the speaker? Due to the international function of it, English is compulsory in our education generally from third grade in primary school through college. And most of the academic examinations require a high qualification of English such as the college entrance exam, master degree enrollment and even doctoral program application. What's more, keeping a certificate of English competence such as College English Test 4 or 6 is the essential for graduates to hunt a job in the fierce competitive market. And when you successfully get a job, in particular, in the official institutes, you also face a kind of test on English ability which greatly affects your promotion and welfare standard. Therefore, English plays a significant part in individual education in terms of the present China educational system. Every one needs to study English as long as you are receiving education. Some study English not only at school but also at some training institute, not only from teachers but from tutors. However, most of us learn it just because it is required in one's education. In other words, every body tries hard to learn English only for academic reason rather than for the practical communication which is actually the essence of learning a language.

Then what are the ways to learn, teach or acquire English? we may divide them generally into two sections with little regard to the real communication with English speaking foreigners which is not commonly available in our study and work. One is about the traditional ways or material-based approaches such as textbook, newspaper, magazine, comic, etc. The other is about the hi-tech ways or machine-based approaches such as computer, projector, CD player, cell pone and so on. In the following chapter, a comparison is made between the material- based traditional approaches and machine-based hi-tech approaches on the influences toward college English learning, teaching and acquisition in Inner Mongolia, China in terms of the author's personal English related experience.

\section{Technology and College English Learning}

The author began her college English study as major at Inner Mongolia Normal University in 2002 and graduated with bachelor degree in 2007. And from 2010 to 2013 the author worked for master degree specializing in English language and literature at Inner Mongolia University. The author's college English education covers nearly a decade which is long enough to witness some notable changes and development if one holds a general view on the college English learning in this area. 
At the very beginning of this decade when the author began to study English as major, English learning mostly depends on the traditional material-based approaches especially with textbooks as the main sources of language knowledge. Each course including the listening and speaking one has one or more textbooks as references for learners to read, recite and practice. Of course, there are some hi-tech machine-based approaches in English learning, but not very common. The high technology available that time is CD players and tape recorders which are usually only applied in listening courses. Due to some under development of economy or technology, the university is not quite well equipped with hi-tech machines for each classroom like computer, projector. Only some of the classrooms have the multimedia facilities and only few of learners can have easier access to the high-tech machines in their English learning. Therefore, for most students they spent most of their study time on reading the printed books, translating what you read into one's mother languages and writing it down. The source was so limited and the content was so fixed and sometimes so out of date. The communication is so monotonous just made between learners and books while there were fewer English speaking foreign teachers available and lack of English language environment. That may best explain why English major students are generally better at reading and writing then listening and speaking. That is why they perform better in paper exams which require primarily reading and writing then in real communication with foreigners which requires mostly speaking and listening. Being restricted too much to the traditional ways of English learning, students tend to become dumb English learners just like the quiet printed textbooks they read.

However, with the fast economic development and stronger financial support in education, at the second half of the decade, situation for English learning at universities was getting better with nearly most of the classrooms equipped with multimedia facilities which can meet the various requirements of different courses providing audio, video, internet access, etc. For students, English learning is no longer just about reading books, but listening, speaking and appreciating. They could be able to listen a lot and speak more. The contents could be so varied, extensive and favorable provided by the digital equipment. English learning was becoming more interesting and practical. Their English comprehensive ability improved a lot in this way. So they were able to learn more attentively, effectively and enjoyably with the help of technology in class time.

Inner Mongolia Normal University. Inner Mongolia Normal University is the biggest comprehensive higher educational institute in Inner Mongolia specialized in nurturing future educators. As for college English learning here, there are two divisions. One is Chinese class scheduled to take four-year study for a bachelor degree and the other is Mongolian class to take five-year study. This part takes the Mongolian division as an example. For Mongolian students, Mongolian is their mother language and Chinese the second one. So English would be the third language in their study to deal with which learning would be surely influenced by the first two languages they are more proficient in. Then which language could be more helpful to their college English learning? Or in which language could students comprehend the third language well, Chinese or Mongolian?

Mongolian may come into first consideration. Actually, that is not always true. In inner Mongolia, Chinese still prevails due to the nearly $79 \%$ large population and being official language of the whole country. Especially in academic area, Chinese is the most acknowledge-able language and widely used one except the specialized field on Mongolian. And when learning English, many terms such as related to grammar or syntax have no equivalent expressions in Mongolian, for many academic references and books are written in Chinese. Students are more familiar with Chinese expressions then Mongolian and also have easier access to Chinese version of exercise or materials on English. What's more, most of high technology devices or digital equipment, software can only recognize Chinese which leads to the limitation of the uses of Mongolian in English learning such as hi-tech machine-based audio and video documents or websites. At Inner Mongolia Normal University during 2002-2007 when the author studied there, the printed textbooks sometimes with Chinese translation were the main source of English learning while hi-tech equipment are rarely available to students. The most common digital devices employed in study were CD players and tape recorders which are only for some particular courses like on listening. Computers and 
projectors are rarely seen in regular learning places. It may sound unbelievable. But considering the economic and social development of that time in this area, it makes sense. Inner Mongolia is the west-northern part of China being the third largest administrative area but with under-developed economy compared to the eastern cities or areas. It is developing faster in recent years thanks to the special West Development Policy issued and executed in 2000, but still having a weaker foundation. Thus, hi-tech equipment like computer were not very common or available in universities; schools here even not in families. At that time, students even did not have a smart phone, not to mention laptop. One would be very happy having a beeper. So for the first few years of $21^{\text {st }}$ century, technology-based college English learning ways in Inner Mongolia might be just CD players and recorders which made great contribution to language development of students adding visual and audio elements in their study experience.

Inner Mongolia University. Around 2010, ten years after the execution of West Development Policy, Inner Mongolia saw a prominent accomplishment particularly in economy. With the ever-growing economic development, schools were given more financial support to improve the learning condition for students. Inner Mongolia University is one example in case where the author worked for three years for master degree from 2010 to 2013. Inner Mongolia University is the most acclaimed top university in Inner Mongolia being the oldest comprehensive higher educational institute established in autonomous regions after the foundation of People's Republic of China and the only one national key university in Inner Mongolia. It was equipped with high standard and high technological facilities for learners such as having the digital library and multimedia classrooms. College English learning here was more convenient, efficient and resourceful. Students can employ multimedia system to present their research work in more impressive and original way which covers various elements like literal, pictorial, audio, etc. they could appreciate English films adapted from the world- known literary works without staring at pages all the time. They could share the electronic academic findings on English or maybe the most discussed English news just by making a few clicks. They also could keep electronic copy of valuable subject references without spending too much time to write it down. They could follow teacher by checking some puzzling information from their smart phone without consulting it after class.

There are so many things for English learners to do about their language study with the high-tech equipment. Having smart phone and computer with access to internet seem indispensable in today's English classes with amazing function that could not be replaced by traditional textbooks. They have made learning English so easy, enjoyable and effective saving time, space and providing enormous and interesting information. Hi-tech machine-based college English learning approaches should really be promoted and developed in universities having its unique characteristics that traditional material-based ones can not be comparable with. But of course that does not mean high technology equipment can take place of the printed textbooks in English learning. Each kind of approaches has their own advantages and strong points as well as its weaknesses. Sometime students just need a textbook to read, to think, to appreciate the words printed with the refreshing paper smelling sitting in a classroom, library or a quiet comfortable place. This is a joy, a kind of pleasure. Therefore, to learn English well, students need absolutely both of them, high-tech machines and printed materials together with other ways not mentioned in this paper for example, communication with native speakers and participation in social practices.

\section{Technology and College English Teaching}

In the above part, the author makes an introduction to the technology-based college English learning at two universities in Inner Mongolia during first decade in this century based on her personal experience. Next comes college English teaching hi-tech approaches mainly applied by the author as a college English teacher at different universities in Inner Mongolia. The author first worked for Hohhot University for Nationalities from 2007 to 2008 and then for Inner Mongolia Normal University from 2010-2012 and now for Chifeng University from 2013. According to the author's experience, a general conclusion could be drawn on the development of college English teaching hi-tech approaches in Inner Mongolia higher educational institutes to show the significant 
part technology plays in language learning.

Hohhot University for Nationalities. Hohhot University for Nationalities is known as the cradle of ethnic elites with commitment to national minority education and culture development. The author first began her college English teaching experience here in 2007 when she graduated from college. So the condition of technology application in English teaching is quite similar to the author's college time as a student. What an English teacher has for class is in most cases a textbook and reference document. The teacher would instruct students to do the reading, check the comprehension and develop a kind of critical thinking only based on the printed textbook contents. Teachers are expected to finish their teaching in a given academic time as scheduled in the course syllabus. Usually one book is for one term of nearly four months. Due to lack of supportive digital devices or technological equipment, English teaching approaches at class seemed unchangeable, monotonous or just stereotyped with no original or different mode to expect. Without the hi-tech approaches, teachers' work tended to only related to paper. Before class one might be busy with writing teaching plans for each class spending a lot of time but hardly presenting it to students. You may keep them only for yourself to review or for your leader to check. Also you may find them not quite convenient to carry and keep. They took too much space together with your textbook and references in your bag and easy to fade with time goes by. There is also a risk to get soaked and burnt which could lead to an irreversible devastating consequence of you hard work. At class, the only medium between teacher and students is the textbook. Every one held an exactly identical book and stared at the identical line at the identical speed. Together, they studied on the book, talked about the book and have test on the book. That is a typical image of traditional class with little technology application in teaching approaches. Without the book, teacher would hardly find something to teach students or to organize interactive activities for both of them. After class, a great deal of paper homework would be a big headache for teachers to check. Say, even though you have a normal amount of teaching task-usually three classes of about 120 students, you have to examine 120 pieces of paper from time to time. You collect, bring home, check and take back to school to return it. It was indeed a time and energy consuming work. You might be interested in research work on English. You needed to go to the school library or other scientific institutes at working time which did not always work for you. You checked many references but most of them are in paper form instead of electronic version. You wrote down the words and statistics in your notebook. And finally you realized it was hard to find any proper devices or equipment to show your interesting findings to the whole class because few classrooms are equipped with computer, projector, etc.

Due to this shortage of technological application, college English teaching tends to be a kind of arduous, enormous and tedious with the traditional approaches. Of course, there were some special classrooms with multimedia equipment which are only available to some certain forums and lectures at Hohhot University for Nationalities around 2007. Nowadays, the application of new technology in school teaching has been broadened much and become available for almost all subject teaching including college English teaching at universities in Inner Mongolia. We may see the close relationship between new technology and college English teaching by Mongolian teachers for Mongolian students in Chifeng University from following analysis.

Chifeng University. Chifeng University is the only one comprehensive higher learning institute in Chifeng, Inner Mongolia offering bachelor and master degree study as well as higher vocational education. College English teaching at this university could be generally divided into five categories based on some special subjects, minority language and academic degrees, namely, postgraduate English, Mongolian college English, Chinese college English, P.A.M college English and professional English. This part focuses on the division of Mongolian College English teaching combined with new technology application at Chifeng University. Mongolian college English teaching is not only for students whose major is about Mongolian but also for students who specialize in other aspects but have received their education in Mongolian. These students are supposed to be able to speak and write Mongolian as their mother language. And for them Chinese is the second language and English might be their third one. Then how could an English teacher conduct teaching for these Mongolian class students? Which language is more used in Mongolian 
English class to teach English, Chinese or Mongolian? Generally the teacher for this division is expected to be Mongolian so that students and teachers could develop closer relationship belonging to the same minority group and could communicate more fluently in the same language and thinking way. How many Mongolian English teachers are available who can speak and write their mother tongue and received education in Mongolian? In College Foreign Languages Teaching Department which is responsible for college English teaching at this university, there are altogether 4 Mongolian English teachers among 33 faculty members. Then how many Mongolian English classes are there? Altogether 8 among 93 classes. We can see from the number that Mongolian English staff is sufficient with each responsible for two Mongolian classes. Then what language do they use most to teach Mongolian students English? Mongolian should be the first choice. As a matter of fact, it is not their mother language in class time but Chinese.

No doubt, Mongolian is the best language to communicate with each other in daily life, but not in academic teaching. The possible reasons for this phenomenon are listed below. First of all, Chinese is the official language of whole country used so widely in every field especially in academic area that most textbooks, papers, references are written in Chinese. Taking English textbooks as a case, most of them are bilingual - English and Chinese. It is hard to find a version with Mongolian instruction, translation or references. That means you have to use English-Chinese books for Mongolian classes. And there are fewer equivalent expressions in Mongolian to translate precisely the English terms and rules such as about the grammar and syntax while Chinese is perfect in this aspect. Therefore both teachers and students get quite accustomed to Chinese expression in English teaching. That also best explains why teachers prefer to write their teaching plans in Chinese rather than Mongolian. More importantly, new technology has posed a big challenge to the use of Mongolian in teaching. Most of high tech-based classroom equipment and digital devices can not read Mongolian. They operate only under Chinese instruction. English teaching software are only Chinese. If teachers prepare electronic teaching plans in Mongolian in a form of PowerPoint or Microsoft Word, the Mongolian spelling software would be needed and the uses of it would also be challenging, for Chinese spelling prevails so much that you use it everywhere anytime while Mongolian spelling on computer is seldom used. Most teachers do not care and can not spell it or not skillful at it. Therefore, even though classroom computer is equipped with Mongolian spelling software, teachers still find it not as convenient and effective as Chinese one. Next comes the uses of mobile phones in English teaching. Nowadays cell phones are the most common electronic devices for individuals which provide so many functions that it acts like a personal computer or even powerful than it. With internet searching available almost anytime anywhere, cell phone can be used for many purposes like information provider in English teaching. Teachers could upload some interesting and proper English internet information to We-chat or QQ to share and discuss with students. Also some assignment could be informed to students through cell phone apps and discussion on English could be carried out online. Still, most apps for communication on phones are designed in Chinese and seldom in Mongolian. We have a Mongolian app similar to We-chat. But it is not very popular among Mongolian with limitation of Mongolian source information. And even some tests or homework could be finished on line which means teacher do not have to check the enormous paper work consuming a lot of time and energy. The check for electronic homework online operated by teaching software is so easy that you may simply need to click a button and so convenient that you can do it anytime anywhere you want as long as internet is accessible. So in the Chinese prevailing environment, new technology application definitely results in less uses of Mongolian in Mongolian English class. However no matter Chinese or Mongolian is the teaching language, the overwhelming function of new technology in college English teaching can be seen obviously which has greatly changed the traditional material-based teaching way and brought out notable effectiveness and development.

\section{Technology and College English Acquisition}

Besides the introduction above to the English learning and teaching hi-tech ways, there are also some technology-based approaches in daily life for teachers and students to acquire English. In 
terms of the present social and economic development of Inner Mongolia, English as a third language for Mongolians could generally acquired from leisure activities such as watching movies and plying computer games, searching online and official statement in public areas such as English version for the names of banks, English announcement at the airport. These acquisition approaches indeed play significant role in one's English ability through enlarging vocabulary, improve listening, developing communicative skill, etc.

Leisure Activities. Although English is not the daily communication language as Mongolian and Chinese for Mongolians, it is still accessible in your free time out of school and work. As English is the global language, it is applied in many aspects especially related to globalization products and activities. For example, searching on Internet is one's favorite thing to do in spare time and many web pages available are designed not only in Chinese or Mongolian but in English. One will not be surprised to see a computer screen full of English and even can easily understand what should be done next according to one's internet experience. For example, when you turn on and turn off the computer, there is always some English instruction. Sometimes you need to enter your user's name and passwords to log in a website without any Chinese direction. Boys are always fond of computer games which are mostly designed in English. they may not know the words but they can play well then become familiar with the expression. We also get used to some brief greeting English while chatting online like see you, hello. And apart from searching on internet, we also watch movies a lot in theatre. That could be a better way to acquire English. Students like science fiction or action movie which are mostly from Hollywood. They try to understand the English speeches with the help of Chinese subtitle. Therefore some leisure activities we like could be one way for us to acquire English quickly and naturally without any study plan to make.

Official Application in Public Areas. In daily life, we always see some English words shown in LED screen as a translation of some official notice, organization names or listen to some English version of announcement and instruction through audio equipment in public areas. For instance, you will find out the banks, schools and some important service industry usually have English version of their institute names or key notes shown on electronic screen. When you deposit or withdraw money on the ATM machine, there is always English instruction for you to read or listen while operating. There is also certain service shown as VIP windows set for special customers who might not know English. At the airport, you always hear some English announcement for each flight about the departure, landing or schedule changes. Many English signs or direction are shown on screen, for example we are most familiar with the sign EXIT lightening in buildings. In a way, new technology seems has a close relation with English always going hand in hand. It makes English so popular among us while it makes life so colorful and convenient.

\section{Conclusion}

This paper makes an analysis on technology-based college English learning, teaching and acquisition as a third language for Mongolians in Inner Mongolia in China based on the author's English related experience. It can be seen from the analysis that new technology has great influence on the promotion, application and development of language. Thanks to new technology, language learning for students becomes so easy, enjoyable and effective with assistance of digital devices. Thanks to new technology, language teaching for teachers seems more inspiring, interesting and influential with more work done on line. Thanks to new technology, language acquisition for both students and teachers has been in a more convenient, communicative and comfortable way through daily exposure to it. However, due to new technology, some language might not make its way through the challenges posed by it. As mentioned in this paper, Mongolian as a minority language would have to give way to Chinese in communication even between Mongolians due to marginalized uses in new technology. To solve this problem, a kind of balance needs to be achieved between the development of technology and language. While technology is getting more and more powerful and popular, we need to have our language more compatible and competitive by learning it, using it and promoting it in our life, work and study. 


\section{References}

[1] Dk Yusimah Pg Hj Amjah: Procedia - Social and Behavioral Sciences, Vol.134 (2014), p.188

[2] John W. Schwieter:Language Learning \& Language Teaching (John Benjamins Publishing Company, America 2013).

[3] L.Nie:Proceedings of 2017 2nd International Conference on Education \& Education Research (Hubei, China, November7, 2017), p.91.

[4] W. Zhang: Proceedings of the 3rd International Conference on Management Science and Innovative Education (Shandong, China, October14, 2017) p.655.

[5] Peng L, Fang W. Heterogeneity of Inferring Reputation of Cooperative Behaviors for the Prisoners' Dilemma Game [J]. Physica A: Statistical Mechanics and its Applications, 2015, 433: 367-378. 